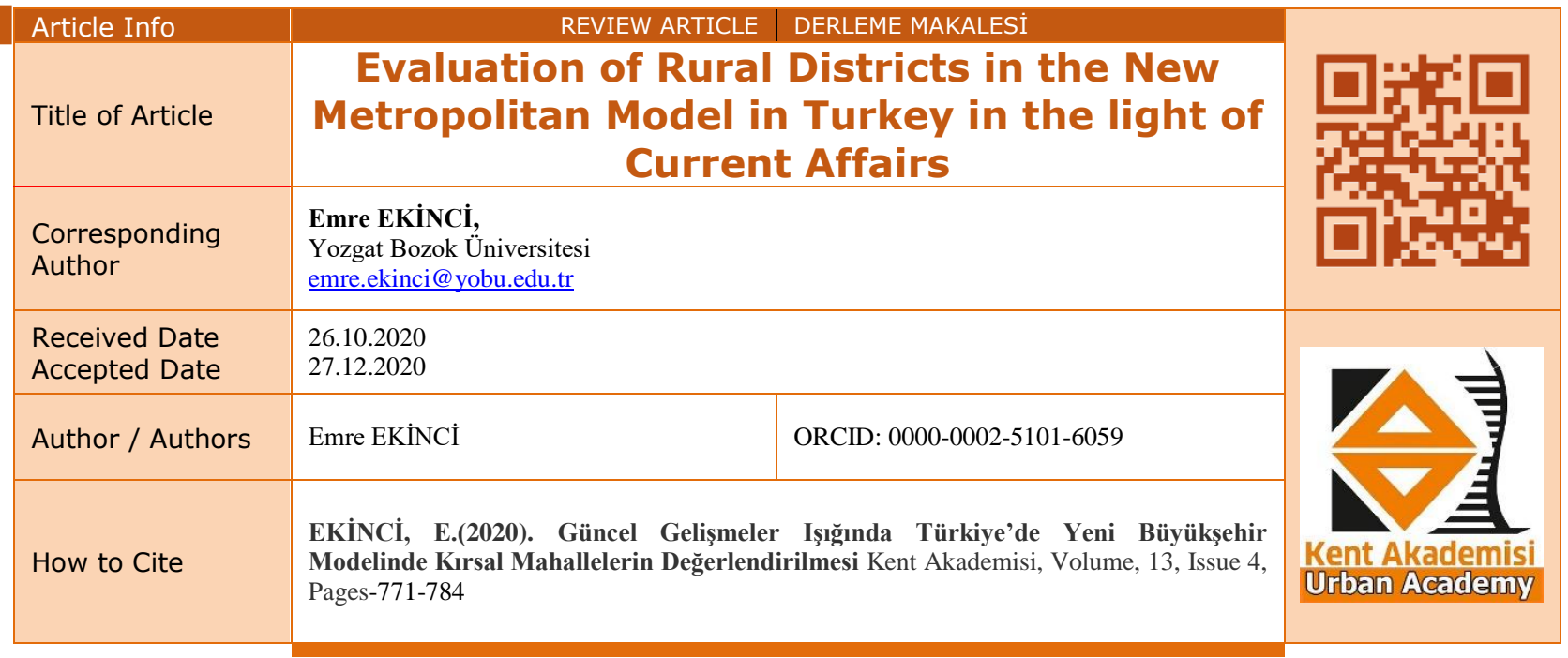

\title{
Güncel Gelişmeler Işığında Türkiye'de Yeni Büyükşehir Modelinde Kırsal Mahallelerin Değerlendirilmesi
}

Emre EKINCí ${ }^{1}$

\begin{abstract}
:
Metropolitan municipality model in Turkey has been transformed into a new form when the changes made in accordance with the law no. 6360 came into force after 2014 local elections. In this model, the local borders of metropolitan cities have been integrated with the borders of metropolitan municipality borders; and the legal entities of all towns and villages came to an end whether they are rural/urban, near/far from the city center and densely populated or not. These units, whose legal entities were abolished, have become districts of the metropolitan municipality of which they are a part. In this way, in the literature these villages and towns which are far from the city and have rural characteristics and stay within the borders of metropolitan municipalities and which were transformed into districts have been called "rural districts". In the study, first of all, the villages and towns called rural neighborhoods in the new metropolitan model were defined, the criticisms directed to the Law No. 6360 within the scope of its effects on rural areas were included, the current official documents were transferred, the ones related to the rural areas in new budget proposal were specified, and as a result, the regulations of the new law, which entered into force on October 16, 2020, were evaluated. The aim of the study was to be a source for researchers who were interested in the subject, in the light of current regulations regarding local governments and to provide a scientific discussion of the better manageability of rural neighborhoods.
\end{abstract}

KEYWORDS: Law No. 6360, metropolitan municipality, rural neighborhood, village, town, local administrations.

\footnotetext{
${ }^{1}$ Yozgat Bozok Üniversitesi
} 
ÖZ:

Türkiye'de büyükşehir belediyesi modeli, 6360 sayılı Kanun ile getirilen değişikliklerin 2014 yılı yerel seçimleri ile birlikte yürürlüğe girmesi ile yeni bir boyuta taşınmıştır. Bu modelde büyükşehir olan illerin mülki sınırı ile büyükşehir belediyesi sınırı bütünleştirilmiş; bu sınırlar içerisinde kalan, kırsal/kentsel, şehir merkezine uzak/yakın, nüfusu büyük/küçük tüm belde ve köylerin tüzel kişilikleri son bulmuştur. Tüzel kişilikleri kaldırılan bu birimler, bağlı bulundukları büyükșehir ilçe belediyelerinin birer mahallesi olmuşlardır. Bu șekilde büyükșehir sınırları içerisinde kalan ve mahalle statüsüne dönüştürülen köyler ve şehirden uzak, kırsal özellik taşıyan beldeler, literatürde "kırsal mahalle" olarak adlandırılmıştır. Çalışmada, öncelikle yeni büyükşehir modelinde kırsal mahalle olarak nitelendirilen köy ve beldeler tanımlanmış, kırsal mahallelere olan etkileri kapsamında 6360 sayılı Kanun'a yöneltilen eleştirilere yer verilmiş, konuya ilişkin güncel resmî belgeler aktarılmış, yeni bütçe teklifinin kırsal alanla ilişkili olanları belirtilmiş ve sonuç olarak mevcut durum ile 16 Ekim 2020 tarihinde yürürlüğe giren yeni yasanın bu kapsamdaki düzenlemeleri değerlendirilmiştir. Çalışmanın amacı, yerel yönetimlerle ilgili güncel düzenlemeler 1şı̆̆ında konuyla ilgilenen araştırmacılara kaynak olmak ve kırsal mahallelerin daha iyi yönetilebilirliğinin bilimsel olarak tartışılmasını sağlamaktır.

ANAHTAR KELIMELER: 6360 sayılı Kanun, büyükşehir belediyesi, kırsal mahalle, köy, belde, yerel yönetimler.

\section{“Güncel Gelişmeler Işığında Türkiye’de Yeni Büyükşehir Modelinde Kırsal Mahallelerin Değerlendirilmesi”"}

\section{GíRIŞ:}

Bu çalışma, Türkiye'de 6360 sayılı Kanun'un yürürlüğe girmesinden günümüze kadar deneyimlenen yeni büyükşehir modelindeki kırsal mahalleleri konu almaktadır. Konu itibariyle öncelikle kent ve kır kavramlarını tanımlamak yerinde olacaktır. Gerek dünyada gerekse Türkiye'de kent ve kır ayrımını net bir biçimde ortaya koymak çok da kolay görünmemektedir (Kartal ve Demirhan, 2015: 386). Kenti, Ulusoy ve Vural (2001:8); "sınırları içinde yaşayan nüfusun geçim kaynaklarını tarım ve hayvancılık dışı uğraşıların oluşturduğu, toplumsal ilişkiler, kültürel alanlar, nüfus yoğunluğu gibi birçok yönden kırsal alanlardan farklı olan yerler" şeklinde tanımlamaktadır. Kırı ise mesleki gruplaşma ve uzmanlaşmanın bulunmadığı, kişilerin daha çok geleneklerine bağlı, örf, adet ve değerlere göre davranışlarını biçimlendirdiği, eğitim oranı kentlerde yaşayanlara oranla daha düşük olan yerleşim birimleri olarak tanımlamak mümkündür. Sosyolojik açıdan kentlerde olması gereken özellikler Erkan'ın (2010:17-18) da ifade ettiği üzere; eğitim seviyesinin kırsal kesime oranla daha yüksek olması, belli bir nüfusa ulaşması, toplumsal normlardan ziyade resmi kuralların olması, tarım sektörü yerine hizmet ve sanayi sektörünün varlığı, geleneksel geniş ailenin yerine çekirdek ailelerin çoğunlukta olması, birincil ilişkilerden ziyade bireyin çıkarlarının öne çıkması, nüfusun heterojen bir yapıda olması, uzmanlaşmaya dayalı iş bölümünün varlığı şeklinde sıralanabilir.

Sosyolojik olarak kent ve kır, yukarıdaki gibi tanımlanabilse de esasen bu kavramların ayrımında en belirgin ölçüt nüfustur. Nüfusu baz alan en önemli hukuki kaynak 1924 sayılı Köy Kanunu'dur. Köy Kanunu'nun 1. Maddesine göre; "nüfusu iki binden aşağ 1 yurtlara (köy) ve nüfusu iki bin ile yirmi bin arasında olanlara (kasaba) ve yirmi binden çok nüfusu olanlara (şehir)" denilmektedir. Kanuna göre nüfusu 20.000'den aşağı olan yerleşimler kır olarak değerlendirilebilir.

Türkiye'de genelde yerel yönetimlerde özelde ise büyükşehir belediye sisteminde köklü değişiklikler içeren 6360 sayılı Kanun yürürlüğe girmeden önce Türkiye nüfusunun \%23'ü kırsal alanlarda, \%77'si ise kentlerde (il ve ilçe merkezlerinde) yaşamaktadır (TUİ, 2012). Kanun'un yürürlüğe girmesinden günümüze kadar toplamda 1.592 belde belediyesinin ve 16.105 köyün tüzel kişilikleri son bulmuştur (E-içişleri, 2020). Yeni büyükşehir modelinde 30 büyükşehir belediyesinin sınırları bulunduğu ilin mülki sınırı olmaktadır. Büyükşehir belediyelerinin sınırları içerisindeki tüm köylerin ve kırsal nitelik taşıyan/taşımayan tüm beldelerin tüzel kişiliklerinin kapatılması ile birlikte bu yerleşimlerde yaşayan kırsal nüfus, belediye nüfusunun içerisine birer mahalle olarak katılarak kentsel nüfusun içerisinde değerlendirilmektedir. $\mathrm{Bu}$ nedenle günümüzde, yukarıdaki kır ve kent nüfus değerleri çok da gerçeği yansıtmayan bir oranda değişmiştir. TUIK'in 2019 yılı verilerine göre Türkiye'de toplam 83.154.997 nüfus 
bulunmaktadır. Bu nüfusun \%92,8'i kentlerde, $\% 7,2$ 'si ise kırda yaşamaktadır. Dünya bankasının verilerine göre ise 2012 yllında Türkiye'de kentlerde yaşayanların oranı \%72 iken 2019 yılında sadece \%3,6 artarak \%75,6'ya yükselmiştir (TheWorldBank, 2020). Dünya Bankası'nın "dünya gelişme göstergeleri” (World Development Indicators) kapsamındaki kır ve kent nüfusu istatistikleri daha gerçekçi görünmektedir.

Dünya Bankası'nın verileri baz alındığında Türkiye'de yaklaşık 21 milyon kişi kırsal alanlarda yaşamaktadır (TheWorldBank, 2020). Kırsal nüfusun giderek kentlere doğru göç yoluyla azalması, beraberinde tarımsal üretime yönelik çıkmazlarla birlikte kentsel sorunların da artmasına sebep olmaktadır. Kırsal nüfusun azalmasında idari ve yasal düzenlemelerin etkisi göz ardı edilmemelidir. Özellikle 6360 sayılı Kanun ile yukarıda ifade edildiği üzere büyükşehirlerde belediye sınırındaki tüm köy ve beldelerin tüzel kişilikleri kaldırılarak ilgili büyükşehir ilçe belediyelerinin birer mahallesine dönüştürülmüştür. Böylece bir yasal düzenleme ile kırsal alanlar, kentsel alanların bir parçası haline getirilmiştir. Artık yeni büyükşehir modelinde kırsal kesimde yaşayan ancak mahalle sakini olan vatandaşlar hizmet talebi için belediye ile muhatap olmaktadır. Bunun yanı sıra gerçekten ve fiilen olmasa da yasaya göre büyükşehirde yaşamanın getireceği yeni ekonomik külfetlerin memnuniyetsizlik yaratıp kırsaldan uzaklaşmaya sebep olma ihtimali de değerlendirilmelidir.

Kanun ile tüzel kişilikleri kaldırılarak mahalle statüsüne dönüştürülen köyler ve şehirden uzak, kırsal özellik taşıyan beldeler, literatürde "kırsal mahalle" olarak adlandırılmışıtır. Tüzel kişiliklerin bir kanun ile son bulmasının anayasaya aykırılığı (Gözler, 2013: 37), kırsal mahallelerde yaşayanlara getirilen mali yük, eskiden köylere ait çayır, mera gibi alanların belediyelerin tasarrufunda olmasının tarım ve hayvancılık faaliyetlerini olumsuz yönde etkileyeceği (Ayyıldız vd., 2016: 284), kırsalda temsil ve siyasal katılım kanallarının daraltılması (Ekinci, 2020c: 9), belediyelerin tarımsal faaliyetlerle ilgili alt yapısının olmaması, mesafe olarak uzak birimlere götürülecek hizmetlerin mali yükü, uzak birimlere götürülecek hizmet kalitesinin düşmesi gibi eleştirilerin hedefi olan yeni büyükşehir modelinde kırsal mahalleler konusu yaklaşık 8 yıldır Türkiye'nin yerel yönetim gündemlerinden birisi olmuştur. Bu tür sebeplerle, kırsal mahallelere yönelik uzun vadede olumlu sonuçlar elde edilebilecek düzenlemelerin yapılması gerekliliği söz konusu olmaktadır. Bu kapsamda AK PARTİ'nin hazırladığı ve 2020 yılı Ekim ayının ilk haftasında nihayete erdirdiği "Yerel Yönetimler Yasa Taslağı" ile 16 Ekim 2020 tarihinde Resmî Gazetede yayınlanarak yürürlüğe giren 7254 sayılı Kanun ile birlikte kırsal mahalleleri düzenleyen hükümlerin 5216 sayılı Kanun’a işlenmesi önem arz etmektedir.

Çalışmanın konusu yeni büyükşehir modelinin kırsal mahallelere olan etkilerini belirtilen bu yeni yasal düzenlemeler 1şı̆̆ında değerlendirmektir. Bu kapsamda çalışmanın amacı kırsal alanlara yönelik düzenlemelerin uzun vadede yerel yönetim sisteminde getireceği sonuçları analiz etmek ve bu alanda yapılacak çalışmalara katkı sağlamaktır.

Çalışmada, öncelikle Türkiye'nin yeni büyükşehir modeli özet olarak açıklanmakta; ardından pozitif hukukta ve kalkınma planlarında mahalle yönetimleri konusu aktarılarak yeni büyükşehir modelinin kırsal mahallelere olan etkileri literatür taraması yöntemi ile değerlendirilmektedir. Bu tartışmalardan sonra ise Türkiye'de konu ile ilgili yasal gelişmeler değerlendirilip önerilerde bulunulmaktadır.

\section{Türkiye'de Kursal Yerleşimler ${ }^{2}$}

Türkiye'de kırsal yerleşimler Yılmaz'a (2019) göre; nüfus büyüklüklerine göre kasaba, belde ve köy; idari taksimata göre ise ilçeler, bucaklar/nahiyeler, divanlar ve muhtarlıklar olarak ayrılmaktadır. Bu başlık altında yalnızca nüfus ölçütüne göre sınıflandırılmış olan köy ve belde yerleşmeleri ile mahalle yönetimleri genel nitelikleri ile aktarılmaktadır.

\footnotetext{
${ }^{2}$ Bu başlık içerisinde yer alan "belde" ve "mahalle" konuları yazarın 2020 tarihli, "6360 Sayılı Kanun'un Temsil ve Hizmet Kalitesi Yönünden Kapatılan Belde Belediyelerine Etkisi ve Vatandaşın Algısı: Hatay İli Örneğì" isimli yayınlanmış doktora tezinden yararlanılarak yazılmış ve kaynakçada belirtilmiştir.
} 
Tablo 1. 2008-2019 Yılları Arası Şehir ve Kır Nüfusları ve Oranları

\begin{tabular}{lllll} 
Yıl & $\begin{array}{l}\text { Şehir Nüfusu (İ ve İlçe } \\
\text { Merkezleri) }\end{array}$ & $\begin{array}{l}\text { Yüzdelik } \\
\text { Değişim }\end{array}$ & $\begin{array}{l}\text { Kır Nüfusu (Belde ve } \\
\text { Köyler) }\end{array}$ & $\begin{array}{l}\text { Yüzdelik } \\
\text { Değişim }\end{array}$ \\
2008 & 53611723 & 75,0 & 17905377 & 25,0 \\
2009 & 54807219 & 75,5 & 17754093 & 24,5 \\
2010 & 56222356 & 76,3 & 17500632 & 23,7 \\
2011 & 57385706 & 76,8 & 17338563 & 23,2 \\
2012 & 58448431 & 77,3 & 17178953 & 22,7 \\
$\mathbf{2 0 1 3}$ & $\mathbf{7 0 ~ 0 3 4 ~ 4 1 3}$ & $\mathbf{9 1 , 3}$ & $\mathbf{6 ~ 6 3 3 ~ 4 5 1}$ & $\mathbf{8 , 7}$ \\
2014 & 71286182 & 91,8 & 6409722 & 8,2 \\
2015 & 72523134 & 92,1 & 6217919 & 7,9 \\
2016 & 73671748 & 92,3 & 6143123 & 7,7 \\
2017 & 74761132 & 92,5 & 6049393 & 7,5 \\
2018 & 75666497 & 92,3 & 6337385 & 7,7 \\
2019 & 77151280 & 92,8 & 6003717 & 7,2 \\
\hline
\end{tabular}

Kaynak: TUIK, 2020.

Tablo 1'deki TUIKK verilerine bakıldığında, 2012 yılından 2013 yılına geçildiğinde şehir nüfusunun birden yaklaşık 10 milyon arttığı görülmektedir. Bir önceki yıla göre şehir nüfusları ile kırsal kesim nüfuslarındaki büyük farklılıkların ana nedeni, 6360 sayılı Kanun uyarınca yapılan idari bölünüş değişiklikleridir. Esasen 12 Kasım 2012 tarihinde çıkan 6360 sayılı Kanun'un birinci maddesinde, büyükşehir sınırları için belirtilen; “...mülki sınırları içerisinde yer alan köy ve belde belediyelerinin tüzel kişiliği kaldırılmış, köyler mahalle olarak, belediyeler ise belde ismiyle tek mahalle olarak bağlı bulundukları ilçenin belediyesine katılmıştır" hükmü 30 Mart 2014 Mahalli İdareler Seçimleri ile yürürlüğe girmiş̧tir (6360 sayılı Kanun Mad. 36). Yani bu sayısal değişiklik hukuken 2014 yılında gerçekleşmiştir. Yukarıda da ifade edildiği gibi belde ve köylerde yaşayan nüfusun genel nüfusa oranı \%7,2 olarak çok azmış gibi görünse de bu tamamen 6360 sayılı Kanun ile bu birimlerin yaklaşık yarısı kadarının büyükşehir belediye sınırlarına mahalle olarak katılmasından kaynaklanmaktadır.

Tablo 1'de yoktur ancak Türkiye'de 1927 yılında kır nüfusunun genel nüfusa oranı \%75,8'dir. Yani günümüzdeki oranların tersidir. Cumhuriyetin ilk yıllarından günümüze kadar kırsal nüfus her zaman kentler lehine azalma eğilimi göstermiştir (Yılmaz, 2016:47). Bu sonuç Türkiye'de kırsal kesimin sorunları dolayısıyla kentlere yoğun göç vermesiyle açıklanabilir.

Her ne kadar Köy Kanunu'nda 20.000 olarak anlaşılsa da Türkiye'de kır ve kenti birbirinden ayırmak için kullanılan nüfus ölçütünün üst sınırında kabul gören sayı 10.000 'dir. Bu nedenle nüfusu 10.000 'in altındaki yerleşimler kasaba, belde, köy ve köy-altı yerleşim birimleri olarak sınıflandırılmaktadır (Yılmaz, 2019: 521). Aşağıda, bu yerleşim birimlerinden köy, belde ve kırsal mahalleleri anlamak açısından mahalle yönetimleri kısaca aktarılacak ve güncel belgeler bazında değerlendirilecektir.

\subsection{Köyler}

Türkiye'de nüfusu az olan, şehir merkezlerine uzak bir konumda bulunan, ekonomisi büyük ölçüde tarıma dayalı olan ve kendisine has sosyolojik bir yapısı bulunan kırsal yerleşmelere köy adı verilmektedir. Ancak "kırsal" sözcüğünün yalnızca köyleri içermemekte olduğunu da belirtmek gerekmektedir. Çünkü "köylerle birlikte belli bir nüfus yoğunluğuna ulaşamayan kasabaları ve muhtarlık olmayan küçük yerleşim birimleri” de kırsal olarak nitelendirilmektedir (Eryılmaz, 2017: 211).

Köy tüzel kişiliklerinin kuruluşunu ve işleyiş̧ini düzenleyen temel kanun 18 Mart 1924 tarihli 442 sayılı Köy Kanunu'dur. Kanun, köyü üç farklı açıdan tanımlamıştır. Bunlar sırayla; "nüfusu iki binden aşağı yurtlar" (Mad.1), 
“Cami, mektep, otlak, yaylak, baltalık gibi orta malları bulunan ve toplu veya dağınık evlerde oturan insanlar bağ ve bahçe ve tarlalarıyla birlikte" teşkil eden yerleşimler (Mad.2) ve "bir yerden bir yere götürülebilen veya götürülemeyen mallara sahip olan ve işbu kanun ile kendisine verilen işleri yapan başlı başına bir varlık” (Mad. 7) şeklindedir.

Köyler, tarihin en eski çağlarından günümüze uzanan ve insanların bir arada yaşamalarından kaynaklanan doğal bir oluşum olarak değerlendirilebilir ${ }^{3}$. Ancak Türkiye'de bu yerleşimlerin hukuki bir zemine dayandırılıp devlet örgütünün içerisinde kamu tüzel kişiliğine haiz bir yerel yönetim birimi haline getirilmeleri Osmanlı dönemine denk gelen 1864 tarihli Tuna Vilayet Nizamnamesi ile Vilayet Nizamnamesine dayanmaktadır (Gözler, 2018: 416). Köylerin tarihsel gelişimine bu başlık altında yer verilmemiş olup; bu başlık altında yalnızca köyün tanımı, köy sayıları ile kırsal kalkınma anlamında köy yerleşimlerin önemine değinilmiştir.

Köy, Gözler'e (2018: 424) göre; “köy sınırları içinde yaşayan nüfusu 150 ila 2000 arasında değişen insan topluluğunun oluşturduğu ve merkezi idare (devlet) karşısında belli bir özerkliğe sahip, ama onun vesayetine tabi olan kamu tüzel kişisidir".

Kentleşme süreci köylerde, daha doğru bir ifadeyle kırsal alanlarda başlamaktadır. Kentlerde yaşanan problemlerin büyük bir çoğunluğunun çözümü köylerdedir. Bu nedenle, köylere yönelik üretilen politikalar oldukça önem arz etmektedir.

Köy sayısı 6360 sayılı Kanun'dan önce 2011 yılında 34.425 iken bu sayı 2020 itibariyle 18.290’a düşmüştür (Eİçişleri, 2020). 1950 yılında, köy nüfusunun toplam nüfusa oranı \%72,5 iken 2019 yılına gelindiğinde bu oran \%7,2’ye düşmüştür (bkz. Tablo 1). Pek tabi oranın bu şekilde çok düşük olması, yukarıda belirtildiği gibi gerçeği yansitmamaktadır.

Tablo 2. 2007-2019 Yılları Arası İlçe, Belde ve Köy Sayıları

\begin{tabular}{|c|c|c|c|c|c|c|}
\hline Yll & Nüfus & $\begin{array}{r}\text { Yıllık } \\
\text { nüfus } \\
\text { artış hızı } \\
(\% \text { ) }\end{array}$ & $\begin{array}{r}\text { İlçe } \\
\text { sayısı }\end{array}$ & $\begin{array}{r}\text { Belde/ilk } \\
\text { kademe } \\
\text { belediyesi } \\
\text { sayısi }\end{array}$ & $\begin{array}{r}\text { Köy } \\
\text { sayısı }\end{array}$ & $\begin{array}{r}\text { Nüfus } \\
\text { yoğunluğu }\end{array}$ \\
\hline 2007 & 70586256 & - & 850 & 2294 & 34438 & 92 \\
\hline 2008 & 71517100 & 13,1 & 892 & 1981 & 34349 & 93 \\
\hline 2009 & 72561312 & 14,5 & 892 & 1978 & 34367 & 94 \\
\hline 2010 & 73722988 & 15,9 & 892 & 1977 & 34402 & 96 \\
\hline 2011 & 74724269 & 13,5 & 892 & 1977 & 34425 & 97 \\
\hline 2012 & 75627384 & 12,0 & 892 & 1977 & 34434 & 98 \\
\hline 2013 & 76667864 & 13,7 & 919 & 394 & 18214 & 100 \\
\hline 2014 & 77695904 & 13,3 & 919 & 396 & 18340 & 101 \\
\hline 2015 & 78741053 & 13,4 & 919 & 397 & 18362 & 102 \\
\hline 2016 & 79814871 & 13,5 & 919 & 397 & 18373 & 104 \\
\hline 2017 & 80810525 & 12,4 & 921 & 396 & 18380 & 105 \\
\hline 2018 & 82003882 & 14,7 & 922 & 386 & 18275 & 107 \\
\hline 2019 & 83154997 & 13,9 & 922 & 386 & 18280 & 108 \\
\hline
\end{tabular}

Kaynak: TUIK, 2020.

\footnotetext{
${ }^{3}$ Bu konuda Aristoteles'in "Politika" adlı eseri incelenebilir: Aristoteles (2017), Politika (Çev. Furkan Akderin), Say Yayınları, İstanbul, s. 23, 25-27.
} 
Tablo 2'deki rakamlara bakıldığında yine 2012 yılında çıkan 6360 sayılı Kanun'un etkisi görülmektedir. Tablo 1'e göre 2012 yılında 1.977 olan belde belediyesi sayısı 2013 yılında 394'e, 34.434 olan köy sayısı ise 18.214'e düşmüştür. Her ne kadar bir kanun ile tüzel kişilikleri kaldırılsa da Türkiye'de hala daha çok sayıda yerleşim kırsal niteliğini korumaktadır. Türkiye'de Karadeniz bölgesinde özellikle dağınık halde yerleşilmiş ve nüfusu az olan çok sayıda köy de bulunmaktadır. Nüfusu az olan ve dağınık olan bu yerleşimler kırsal alanlara götürülen hizmetin maliyetini de arttırmaktadır. Dağınık yerleşimler aynı zamanda birlikte iş yapma olanağını da ortadan kaldırmaktadır. $\mathrm{Bu}$ da kırsal kalkınma çabalarını sekteye uğratmakta ve kırdan kente göçü tetiklemektedir.

\subsection{Beldeler}

Türkiye'nin mülki idare yapısı içerisindeki kentsel yerleşimler il ve ilçe olarak adlandırılmaktadır. İl ve ilçelerin aynı zamanda yerel yönetim birimi olarak belediyeleri de bulunmaktadır. Belde ise içinde mülki idare birimi olmayan yani ilçe merkezi özelliği taşımayan ama belediyesi bulunan yerleşim yerleri için kullanılan hukuki bir tanımlamadır.

Esasen belde, memleket, şehir, diyar, yöre anlamında Arapça bir sözcüktür. Bu kelime genelde belediye teşkilatı bulunan bütün yerleşimleri; il merkezlerini, ilçe merkezlerini ve "belde" adı verilen yerleşmeleri kapsamaktadır (Özçağlar, 2005:13-14). Belde, TDK'nın genel Türkçe sözlüğünde ise; "ilçeden küçük, belediye ile yönetilen yer” ile "mekân, yer, çevre" olarak tanımlanmıştır. Bir başka tanıma göre ise belde, "bir köy sınırları içerisinde gelişip büyüyen bünyesinde belediye örgütü kurulmuş merkezi yönetim bakımından ilçe veya il merkezliği görevi üstlenmemiş kasaba ve şehirlere” denilmektedir (Özçağlar, 1996: 22).

Belde hem sosyolojik hem de hukuki açıdan tanımlanabilir. Sosyolojik açıdan, kent ile kırsal alan özelliklerini içerisinde barındıran ancak kentsel ilişkilerin kıra göre daha ağır bastığı yerleşim yerleri olarak tanımlanabilir. Hukuki açıdan ise mülki idaresi bulunmayan belediye şeklinde tanımlanabilir. Kısacası belde, ilçeden küçük köyden büyük hem kentin hem de kırın olanaklarına sahip belediye örgütü ile yönetilen yerleşim birimidir.

Belde belediyeleri, ilgili beldede hayatını sürdürmekte olan yerel vatandaşların kendi isteği ile seçmiş olduğu temsilciler vasıtasıyla yönetilen, bütçesi ve yapısı özerk olan kamu tüzel kişiliğine haiz temel örgütlerden birisi olarak da ifade edilir.

Belde belediyelerinin 6360 sayılı Kanun’un yürürlüğe girmesinden sonra bağlı bulunduğu büyükşehir ilçe belediyelerinin birer mahallesi statüsüne sokularak tüzel kişilikleri kaldırılmıştır. 6360 sayılı Kanun'un getirmiş olduğu bunun gibi değişikliklere yönelik olumlu ve olumsuz değerlendirmeler bulunmaktadır (Ekinci, 2020: 93-96). Olumlu değerlendirmeler, genellikle hizmet kalitesinin artması beklentisine, olumsuz değerlendirmeler ise demokratik bir yerel yönetim yapısından uzaklaşma kaygısına dayanmaktadır. Demokratik yönetimden uzaklaşma kaygısının kaynağında köylerin ve belde belediyelerinin tüzel kişiliklerinin kaldırılarak bağlı olduğu ilçenin mahallesi statüsüne dönüştürülmesi bulunmaktadır.

2019-2023 yıllarını kapsayan On Birinci Kalkınma Planı'nda 11 ve 12 Aralık 2017 tarihleri arasında "Yerel Yönetimler ve Hizmet Kalitesi Özel İhtisas Komisyonu” birinci aşama toplantısında: 6360 Kanun uygulaması sonrasında tüzel kişilikleri olmayan bir mahalle statüsüne dönüşerek temsil niteliğini kaybetmiş yerleşim yerleri için "mahalle yönetiminin yapısal eksikliklerinden kaynaklanan sorunlar” başlıklı sorun belirlenmiş, bunun çözümü için "mahalle yönetiminin hukuki zeminin ihtiyaca göre geliştirilmesi” politikası öngörülmüş ve "Mahalle Muhtarlığı Kanunu'nun çıkarılması" hedeflenmiştir. Bu hedef doğrultusunda ise "mahalle muhtarlığının, mahallede merkezi idare için idari görevler yapan, belediye için mahallede idari ve sosyal görevler üstlenebilen, yönetime katılabilen, mahallesini devlet ve belediye nezdinde temsil edebilen bir yönetim birimi” olması yönünde bir eylem planı açıklanmıştır.

\subsection{Mahalleler}

Türkiye'de her il, ilçe çeşitli isimlerle ifade edilen mahallelerden oluşur. Adresler, mahallelere göre verilir. Şehirlerde geçmişi çok eskilere dayanan mahalleler vardır. Nüfusu yoğun, sosyal, ekonomik ve kültürel açıdan oldukça zengin mahalleler mevcuttur. 5393 sayılı Belediye Kanunu mahalleyi; "Belediye sınırları içinde, ihtiyaç ve öncelikleri benzer özellikler gösteren ve sakinleri arasında komşuluk ilişkisi bulunan idarî birim” olarak tanımlamıştır. 
Aynı kanunun 9. Maddesine göre; "Belediye sınırları içinde mahallelerin kurulması, kaldırılması, bunların birleştirilmesi, bölünmesi, adları ile sınırlarının belirlenmesi veya değiștirilmesi, belediye meclisinin kararı ve kaymakamın görüşü üzerine valinin onayı ile olmaktadı’”. Nüfusu 500'ün altında belediye sınırları içerisinde mahalle kurulamayacağı hükmü de mevzuatımızda mevcuttur (Mad. 9/2- 6360 Sayılı Kanun ile eklenmiştir). Türk pozitif hukukunda mahalle; belediye, köy veya il gibi bir yerel yönetim birimi olarak değerlendirilmemekte; tüzel kişiliği bulunmamaktadır. Kamu tüzel kişiliğinin bulunmaması onları hukuki bir varlık olmaktan çıkarır. Yani mahalleler, hak ve borç altına giremeyip, kararlarını kendileri alamamakta; nakit idarelerini kendileri yapacak düzeyde bir örgütlenmeleri bulunmamaktadır.

Yeni belediye yasası (5393 sayılı Kanun) ile birlikte mahalleler belediyelerin bir parçası haline getirilmiştir. Bu kapsamda belediyeler; "mahallenin ve muhtarlığın ihtiyaçlarının karşılanması ve sorunlarının çözümü için bütçe imkânları ölçüsünde gerekli ayni yardım ve desteği sağlar; kararlarında mahallelinin ortak isteklerini göz önünde bulundurur ve hizmetlerin mahallenin ihtiyaçlarına uygun biçimde yürütülmesini sağlamaya" çalışmaktadır (Mad. 9/3).

Mahallenin organları da köyün organlarına benzer özellik taşımaktadır. Mahalle, "muhtar" ve "ihtiyar heyeti” denilen iki organdan oluşmaktadır. Bu organlar ve üyeleri "2972 sayılı Mahalli İdareler ile Mahalle Muhtarlıkları ve İhtiyar Heyetlerinin Seçimi Hakkında Kanun” ile belirtilen hükümlerdeki esas ve usullere göre mahallede yaşayan seçmenler tarafından doğrudan doğruya beş y1l için seçilir. Siyasi partiler bu seçimlere aday gösteremezler. İhtiyar heyeti üyeliği ile muhtarlık kamu görevliliği ile bağdaşmaz.

Mahallenin görevleri ise "10 Nisan 1944 tarih ve 4541 sayll Şehir ve Kasabalarda Mahalle Muhtar ve İhtiyar Heyetlerinin Teşkiline Dair Kanun” da ayrıntılı olarak düzenlenmiştir. 24 Haziran 2018 tarihinde birlikte yapılan TBMM ve Cumhurbaşkanlığı seçimleri sonucunda Cumhurbaşkanının Ant içerek göreve başladığı tarihte 698 sayılı KHK ile ilgili kanunun 3. ve 23. Maddeleri değiştirilmiştir. Kanunun 3. Maddesinin 17. Fikrasında "İcra vekilleri heyetince halkın ihtiyaçlarını karşılamak ve amme hizmetlerini kolaylaştırmak üzere karar altına, alınacak işlerden o mahalleye taalluk eden kısımları tatbik etmek" maddesindeki "icra vekilleri heyetince" ibaresi yerine "Cumhurbaşkanınca" ibaresi eklenmiştir. 23. Maddesinde de "Bu kanunun tatbik şekilleri hakkında bir yönetmelik Cumhurbaşkanınca yapılır." Şeklinde değişiklik işlenmiştir. Aynı zamanda "5393 sayılı Belediye Kanunu” madde 9'a göre; "Muhtar, mahalle sakinlerinin gönüllü katılımıyla ortak ihtiyaçları belirlemek, mahallenin yaşam kalitesini geliştirmek, belediye ve diğer kamu kurum ve kuruluşlarıyla ilişkilerini yürütmek, mahalle ile ilgili konularda görüş bildirmek, diğer kurumlarla iş birliği yapmak ve kanunlarla verilen diğer görevleri yapmakla yükümlüdür.”

Türkiye Cumhuriyeti Cumhurbaşkanlığı Strateji ve Bütçe Başkanlığı tarafından hazırlanan On Birinci Kalkınma Planı'nda (2019-2023) mahallelere de yer verilmiştir. Örneğin planın 675. Maddesinde; "Kamusal alanların erişim ve güvenliğinin artırılması için mahalle bazında kırılgan kesimlere yönelik olarak yerel yönetimlerin ihtiyaç analizi yaptırması ve hizmet kalitesinin artırılması desteklenecektir" denmektedir. Yine plana göre; mekânsal planlama sisteminin oluşturulması, "mahalle düzeyinde etkili katılım mekanizmalarını, izleme ve denetleme süreçlerini”" kapsayacak biçimde geliştirileceği ve bunun planlaması ve uygulamasının da yerel yönetimler tarafından yapılacağı ifade edilmiştir. Mahalle kültürünün geliştirilmesi, kentsel aidiyet ve kent bilincini geliştirecek strateji ve uygulamaların yaygınlaştırılması, mahalle düzeyinde "kentsel veri altyapısının oluşturulması için teknik altyapının güçlendirilmesi” gerektiği konuları da mahalleler ile ilgili konular arasındadır.

\section{Güncel Resmî Belgelerde Kırsal Alanlarla İlgili Değerlendirmeler}

Tablo 1 ve Tablo 2'de belirtildiği üzere; Türkiye'de mevcut nüfus ve yerleşim dağılımı ile kırsal kesimde yaşayan vatandaşların kentlere göç etmesi neticesinde oluşan kentsel ve kırsal sorunlara yönelik değerlendirmeler bazı resmî belgelerde yer almaktadır. Güncel olarak 2010 ile 2023 yıllarını kapsayan KENTGES- Bütünleşik Kentsel Gelişme Strateji ve Eylem Planı bu kapsamda değerlendirilebilir. Bu planda kırsal alanlara ilişkin değerlendirme şu şekilde aktarılmıştır (ÇŞB, 2010: 6): 
"Kentleşme süreci, kentlerin kırsal alanlara yayılması biçiminde geliştiği için, kırsal yerleşmelerin fiziksel, sosyal ve ekonomik yapıları üzerinde dönüştürücü etkisi olmaktadır. Diğer yandan, yatırım projeleri, kırsal alanları doğrudan etkilemektedir. Kırsal alanların kent üzerindeki en belirgin etkisi ise bu yerleşimlerden kentlere göç şeklindedir. Aslında göçün hem kırsal hem de kentsel alanlar üzerinde olumsuz etkisi olmaktadır. Nüfusun terk ettiği ve ülke ekonomisine katkısının azaldığı kırsal alanlar, buna karşın taşıyabileceğinden fazla nüfusu barındırmaya çalışan kentsel alanlar, göç olgusunun etkisinin çift taraflı olduğunu göstermektedir. Kırsal kalkınmaya yönelik sistemli stratejilerin geliştirilmesi ve uygulanabilmesi önem taşımaktadır”.

Kırsal alanlarla ilgili bir diğer değerlendirme de 2014 ve 2023 yıllarını kapsayan BGUS - Bölgesel Gelişme Ulusal Stratejisi'dir. Bu belge T.C. Kalkınma Bakanlığı tarafından hazırlanmış ve 24.03.2015 tarih ve 29305 (mükerrer) sayılı Resmî Gazete'de yayınlanmıştır. Bu belgede ise kırsal alanla ilgili aşağıdaki değerlendirmelerde bulunulmuştur (KB, 2014: 92):

\begin{abstract}
"Planlı dönemin başından beri, ülkemizdeki kırsal alan yerleşim deseni, kırsal kalkınmanın önündeki en önemli engellerden biri olarak kabul edilmiştir. Kırsal yerleşim deseninin; küçük, dağınık ve parçalı yerleşim birimlerinden oluşması kırsal kalkınma politikalarının etkin bir şekilde hayata geçirilmesini sınırlamıştır. Gerek tarımdaki yapısal dönüşüm gerekse kırdan kente göç nedeniyle ekonomik ve demografik açıdan kalkınma için gerekli rasyonel ölçekten uzaklaşan kırsal yerleşimlerin artışı nedeniyle topyekûn kırsal kalkınma yavaşlamakta ve faaliyetlerin etkinliği azalmaktadır. Türkiye'de kırsal yerleşimler idari ayrıma göre, il ve ilçe merkezleri dişında kalan tüm beldeler ve köyler olarak tanımlanırken, diğer bir tanıma göre ise nüfusu 20 binden düşük tüm yerleşim yerlerini kapsamaktadır. İkinci tanım temel alındığında bazı ilçe merkezleri de kırsal alan kapsamına girmektedir”.
\end{abstract}

On Birinci Kalkınma Planı’nın “Kırsal Kalkınma” başlığında ise kırsal alanlar ile ilgili; "köylerin mahalli müşterek nitelikli altyapı ve üst yapı ihtiyaçlarının giderilmesi için büyükşehir olmayan iller için KÖYDES, köy ve beldeden mahalleye dönen yerleşim yerlerinde ise Büyükşehirlerin Kırsal Altyapısı Projesi (KIRDES) kapsamında köylerin ve beldelerin kaliteli ve erişilebilir yol ağı, içme suyu, atık su tesisi, küçük sulama tesisi yapım işleri için finansal destek sağlanacaktır" denilmektedir. Bu kapsamda 6360 sayılı Kanun sonrasında belde ve köy tüzel kişiliği kaldırılarak büyükşehir belediyelerine bağlı birer mahalle statüsüne dönüşen yerleşim yerlerinde kaliteli hizmet alınması için proje ön görülmüştür.

Dikkat edilirse yukarıda aktarılan tüm plan, proje, strateji belgeleri esasen kırsal alandan kente olan göçü azaltacak politikalar üretmeyi hedef almaktadır. Bu sayede kırda yaşayan halkı bulunduğu coğrafyada memnun edebilecek düzeyde hizmet sunulması önemlidir. Kırsal alanların en büyük sorunlarından birisi bu bölgelere kentlerdeki olanakların (sosyal, kültürel, ekonomik, temel kentsel hizmetler vb.) sağlanamamasıdır. Kentler hem yoğun nüfusun ekonomik avantajlarını kullanarak hem de bu avantajın bir yansıması olan belediye örgütlerinin hizmetlerinden faydalanarak kırsaldan her zaman daha cazip bir haldedir. Bu nedenle yerel yönetimlerde yapılacak düzenlemelerde ilk olarak kırsal alanların verimli yönetilebilirliği ve ilgili birimlerin etkin hizmet sunmaları sağlanmalıdır.

Türkiye'de kırsal alanlara içme suyu, kanalizasyon gibi kamusal altyapı hizmetleri 2005 yılından önce Köy Hizmetleri Genel Müdürlükleri tarafından sunulmuştur. Bu kurum 13.05.2005 tarih ve 5286 sayılı Kanun ile kaldırılmıştır (İstanbul ve Kocaeli hariç). Kurumun görev ve yetkileri, taşınmaz malları, araç ve elemanları ile beraber İl Özel İdareleri'ne devredilmiştir. 2014 yerel seçimleri ile yürürlüğe giren 6360 sayılı Kanun ile ise Büyükşehir Belediyesi olan tüm illerde İl Özel İdareleri kaldırılmış ve kırsal alana hizmetler sunma görev ve yetkisi artık Büyükşehir Belediyelerine geçmiştir.

6360 sayılı Kanun, büyükşehirlerdeki tüm kırsal alanları bağlı bulundukları büyükşehir ilçe belediyesinin bir mahallesi yaparak bu yerleşimlere kentsel hizmetlerin götürülmesinin önünü açmıştır. Ancak bu dikkate değer gelişmenin olumsuz sonuçları da olmuştur. Bir kere köylü artık kendi kendini yönetecek demokratik organlara sahip değildir. Köylü, kendi içinden, kendisini yönetecek köy muhtarını ve ihtiyar heyetini artık seçememektedir. Köy, artık tüzel kişiliğini kaybederek büyükşehir belediyesinin kontrolü altında bir mahalle konumuna dönüşmüştür. Yeni büyükşehir modelinde gerçek hayatta köylü ancak hukuken kentli olan köy halkı belli başlı mali külfetlerle de karşı 
karşıya kalmaktadır. Bu konu ile ilgili yasal gelişmeler ve yeni büyükşehir belediyesi modelinin diğer konular üzerinde kırsal alanlara etkileri aşağıdaki başlıktan itibaren değerlendirilmektedir.

\section{Yeni Büyükşehir Modelinin Kursal Mahallelere Etkileri}

6360 sayılı Kanun ile yukarıda belirtilen değişikliklerin yanı sıra kırsal alanlarla ilgili olarak; 5216 sayılı Büyükşehir Belediyesi Kanunu'nda değişiklik yapılmış ve 7. Maddesinin son fikrasına; "Büyükşehir ve ilçe belediyeleri tarım ve hayvancılığı desteklemek amacıyla her türlü faaliyet ve hizmette bulunabilirler" hükmü eklenmiştir. Bu sayede büyükşehir ve ilçe belediyelerinin tarım ve hayvancıllk faaliyetleri ile eskisine nazaran daha yakından ilgilenme imkânı doğmuştur.

Kanun aynı zamanda, orman köyleri ve orman köylüsüne tanınan hak, sorumluluk ve imtiyazların orman köyü iken mahalle statüsüne dönüşen yerleşim birimleri için devam edeceğini öngörmüştür. Aynı zamanda bir belediyeye katılarak mahalleye dönüşen köy, köy bağlısı ve belediyeler tarafindan kullanılmakta olan mera, yaylak, kışlak gibi yerlerden bu mahalle sakinleri ve varsa diğer hak sahiplerinin "4342 sayılı Mera Kanunu" hükümleri çerçevesinde faydalanmaya devam edeceğini de öngörmektedir. Aynı zamanda Kanun, öncesinde köy tüzel kişiliği olan ve mahalleye dönüşen yerleşim birimlerinde orman mevzuatına göre yaşayanların haklarını korumuş, ancak eskiden belde belediyesi olan şimdi ise mahalle olan yerleşim birimleri ile ilgili herhangi bir düzenleme yapmamıştır. Ancak bu eksiklik 27 Şubat 2014 tarihli 6526 sayılı Kanun ile giderilmiştir (TBB, 2014:5). Görev ve sorumluluk alanları daha öncesinde ilin mülki sınırına genişlemiş olan İstanbul ve Kocaeli büyükşehirlerinde bulunan köylerin de tüzel kişilikleri kaldırılmış ve bağlı bulundukları ilçe belediyesinin bir mahallesi olmuştur (Mad. 1).

Bunlara ek olarak tüzel kişiliği kaldırılarak ilçe belediyelerine bağlanacak olan köylerde; önceki haliyle, emlak vergisi ile 2464 sayılı Kanun'a göre alınması gereken vergi, harç ve katılım payları 5 yıl süre ile alınmayacaktır. Bu sürenin başlangıç tarihi ise 30 Mart 2014'tür. Bu süre anlaşılacağı üzere 30 Mart 2019 tarihinde bitmiştir. Aynı zamanda mahalleye dönüşecek olan köylerde 5 yıl süreyle "içme ve kullanma suları için alınacak ücret ... en düşük tarifenin \%25'ini geçmeyecek şekilde" belirlenmiştir. Ancak bu düzenlemede 27 Aralık 2018 tarihinde 7159 sayılı Kanun'un 6. Maddesi ile değişikliğe gidilerek yukarıda "5 yıl" olan muafiyet süresi uzamıştır. Bu haliyle emlak vergisi ile 2464 sayılı Kanun'a göre alınması gereken vergi, harç ve katılım payları 31/12/2022 tarihinde kadar alınmayacaktır. Aynı zamanda bu yerlerde içme ve kullanma suları için alınacak ücret de 31/12/2022 tarihine kadar en düşük tarifenin $\% 25$ 'ini geçmeyecek şekilde belirlenmiştir. Bu tarihten itibaren vergi ödeyecek olan kırsal mahalle sakinlerinin bu düzenlemeden çok da memnun olmayacağı açıktır. Ancak yine de ilgili tarihten sonrasını beklemek gerekmektedir.

Yeni büyükşehir modeli ile kent ölçeği mülki sınıra kadar genişlemiş ancak tüzel kişilikleri kapatılan belde ve köy gibi kırsal yerleşim birimlerinin kendilerini yönetme hakları ellerinden alınarak temsiliyet kaybı da ortaya çıkmışır (Dik, 2014: 77). Bunun yanı sıra üreticinin (bir taşınmaz maliki ise) emlak vergisi ödemeye başlaması, tarladaki, yayladaki ve meradaki suyunun büyükşehir şebeke su fiyatı ile fiyatlandırılması Türkiye'de suyun yaklaşık \% 75 'inin tarımda kullanıldığı düşünüldüğünde (Mert, 2014), yine yöre halkında memnuniyetsizlik yaratacağı söylenebilir.

Ünal (2016: 50); “yerel yönetimlerin kırsal mekanla uğraşılarının sadece tarım ve hayvancıllı̆̆ desteklemek" olmadığını; aynı zamanda kırsal alanların planlanması, bu alanlar hakkında kararların verilmesi ve yürürlüğe konulması hem tarım ve hayvancılığın sürdürülebilirliğini hem de geliştirilmesini sağladığını ifade etse de yeni büyükşehir modelinin kırsal mahallelerdeki sürdürülebilir tarımla alakalı bir eleştiri Hazar (2017: 139) tarafından şöyle yapılmıştır:

"Bugün tarım sektörü, konvansiyonel tarım yapan büyük firmalar haricinde her geçen gün küçülmektedir. Koşullar değişmedikçe, küçük üretici tarımının sürdürülebilirliği mümkün değildir. Hayvancılıkla uğraşan köylülerin de 'mahalle içerisinde otlayan hayvanları' kentli komşularınca şikâyet edilirse ne yapacakları meçhuldür. Dolayısıyla, köylü gitgide tarım ve hayvancılıktan uzaklaştırılmaktadır ve mahalleye dönüşen köylerdeki ekilmeyen toprakların imara açılması riski, kırkent çeperindeki tehditlerin başında gelmektedir".

Yeni büyükşehir modelinin köylere yönelik bir diğer etkisi ise muhtarın yetkileri ile alakalı olmaktadır. Bu şekliyle kırsal mahalle muhtarı konumunda olan eski köy tüzel kişiliğinin seçilmiş temsilcisi artık köy orta mallarından ve 
mera alanlarından sorumlu değildir (Hazar, 2017: 138). Kısacası bu modelde köylü kendi kararlarını vermekten uzaklaşmış, merkezi bir karar mekanizmasına bağlı kalmıştır.

Kırsal alanlarla alakalı olarak yeni büyükşehir modeline getirilen bir diğer eleştiri de muhalefet (CHP) tarafından yapılmıştır. Bu bağlamda, TBMM İçişleri Komisyonu Raporu'nda (2013: 17) aşağıdaki eleştiriler yapılmıştır:

1.“Kentsel ve kırsal yerleşmeler sınıflandırılmalı, bunlar 'kentsel belediye' ve 'kırsal belediye' ana sınıfları içinde sosyoekonomik özelliklere uygun yönetim modellerine kavuşturulmalıdır. Ülkemizin tarımsal ve sınai üretimini mümkün kılmak, artırmak, ülke geneline dengeli biçimde yaymak, ancak bünyeye uygun yönetim modelleri ile gerçekleştirilebilir".

2.“Anayasa'nın 126. Maddesine göre 'illerin idaresi yetki genişliği esasına dayanır'. Bu hüküm, 1961 Anayasası ile 1982 Anayasası'nda aynıdır. Oysa, 1924 Anayasası'nda 'illerin idaresi yetki genişliği ve görevler ayrılığı esaslarına dayanır' hükmü yer almaktaydı; görevler ayrılığı hükmü 1961'de kaldırılmıştır. Bu doğrultuda, il özel idareleri il genel idaresi karşısında ikincil konumda kalmıştır. Büyükşehir belediyesi, bir 'yerel yönetim türü'dür; Yerinden yönetim esası kapsamında yer alır. Dolayısıyla, büyükşehir belediyesi modelinin bu hüküm bakımından da mülki sınırlarda kurulması olanağı yoktur. Yerinden yönetim esasına dayanan büyükşehir belediyesi modelini iller düzeyinde kurmak Anayasa'ya aykırıdır".

Bunların dışındaki bir sorun alanı da imar konusudur. Büyükşehirlerin kırsal mahallelerindeki tarım topraklarının, alınacak bir meclis kararı ile arsa niteliğine dönüştürülüp imara açılabilmesi, belediyelerin tarım ve hayvancılığı yönetecek yetki ve kapasitesinin olmayışı gibi sorunlar da yine kırdan kente göç sonucunu doğuracaktır. Getirilecek mali yükle birlikte çiftçi, tarımla uğraşmanın mali getirisinin çok da mantıklı olmadığı sonucunu çıkaracak ve yine kentlere göç etmek isteyecektir. Bu sorunun kökten çözümü için ortaya çıkan sonuçlar; sosyal, ekonomik, kültürel, yönetimsel, siyasi ve hukuki yönden etraflıca analiz edilmeli ve bu doğrultuda uygun bir politika belirlenerek ilgili düzenlemelerin yapılması gerekmektedir.

\section{Kursal Mahallelere Yönelik Yeni Gelişmeler}

Yukarıda, son yıllarda gerçekleştirilen kırsal yerleşimlere yönelik kalkınma hedefleri, stratejileri ve planları aktarılarak yeni büyükşehir yasası olarak bilinen 6360 sayılı Kanun'un kırsal alanlarda meydana getirdiği ve getirecek olduğu sonuçlardan, bu modelin kırsal mahallelere etkisine yönelik eleştirilerden bahsedilmiştir. Yeni büyükşehir modelinde büyükşehir ilçe belediyelerinin mahallesi olarak statüsü değişen eski belde ve köylere yönelik son günlerde önemli yasal adımlar da atılmıştır. Özellikle bu mahalleleri ilgilendiren ve Büyükşehir Belediye Kanunu'nda önemli değişiklikler öngören yasa teklifi 30 Eylül 2020 tarihinde TBMM'ye AK PARTİ tarafindan sunulmuştur. Bu teklif ise 07 Ekim 2020 tarihinde TBMM Plan ve Bütçe Komisyonunca kabul edilerek 16 Ekim 2020 tarihinde Resmî Gazete'de yayınlanmış, 7254 sayılı Kanun olarak yürürlüğe girmiş ve kırsal mahalleleri düzenleyen hükümleri 5216 sayılı Kanun'un Ek 3. Maddesine işlenmiştir. Bu kapsamda; kırsal yerleşim özelliği taşıyan mahallelerin "kırsal mahalle" olarak nitelendirileceği ve bu doğrultuda bazı vergi avantajlarından yararlanacağı Büyükşehir Belediye Kanunu'nda yapılan değişiklikle hüküm altına alınmıştır. Bu kapsamda kanun teklifinin genel gerekçesine göre (Mad. $13)$;

"Büyükşehir Belediyesi sınırları içinde bulunup sosyo-ekonomik durumu, şehir merkezine uzaklı̆ğ, belediye hizmetlerine erişilebilirliği, mevcut yapılaşma durumu ve benzeri hususlar dikkate alınarak kırsal yerleşim özelliği taşıdığı tespit edilen mahalleler, kırsal mahalle kabul edilecektir". Bunun için ilgili ilçe belediye meclisinin kararı ve teklifi üzerine, büyükşehir belediye meclisinin en geç 90 gün içinde karar alması gerekecektir.

Bu belirleme, mahalle düzeyinde yapılacaktır. Ancak tamamı kırsal mahalle tespit edilmeyen diğer mahallelerde de 10 bin metrekareden az olmamak kaydıyla kırsal yerleşik alan belirlenebilecektir. Ayrıca (7254 Sayılı Kanun Mad. 10);

"Kırsal mahalle veya kırsal yerleşik alan olarak belirlenen yerlerde; gelir vergisinden muaf esnaf ile basit usulde gelir vergisine tabi mükellefler tarafından işyeri olarak kullanılan bina, arsa ve araziler ile mesken amaçlı kullanılan binalar ve zirai üretimde kullanılan bina, arsa ve araziler Emlak Vergisinden muaf" olacaktır. 
Hükümetin, bu teklif ile kırsal mahallelerde yaşayan küçük esnafın vergi yükünü hafifletmek ve işyerlerinin kırsalda devamını sağlamak için teşvik etmek amacında olduğu söylenebilir. Aynı zamanda kırsal mahallelerde, ticari, sınai ve turistik faaliyetlerde kullanılan bina, arsa ve araziler için emlak vergisi \%50 indirimli uygulanacaktır.

"Kırsal mahalle veya kırsal yerleşik alan olarak belirlenen yerlerde, Belediye Gelirleri Kanunu uyarınca alınması gereken bina inşaat harcı ile imarla ilgili harçlar alınmayacak; bu kanuna göre alınması gereken diğer vergi, harç ve harcamalara katılma payları \%50 indirimli" olacaktır.

“Bu yerlerde içme ve kullanma suları için alınacak ücret, en düşük tarifenin iş yerleri için yüzde 50'sini, konutlar için \%25'ini geçmeyecek şekilde belirlenecek. Vergi Usul Kanunu uyarınca bilanço esasına göre defter tutan mükellefler için bu fikrada belirtilen muafiyet ve indirimler" uygulanmayacaktır.

Bir diğer önemli hüküm ise; “... kırsal mahalle veya kırsal yerleşik alan olarak belirlenen yerler hakkında 12/11/2012 tarihli ve 6360 sayılı On Dört İlde Büyükşehir Belediyesi ve Yirmi Yedi İlçe Kurulması ile Bazı Kanun ve Kanun Hükmünde Kararnamelerde Değişiklik Yapılmasına Dair Kanunun geçici 1 inci maddesinin on beşinci ve yirmi dokuzuncu fikraları uygulanmaz" hükmüdür (7254 sayılı Kanun Mad. 10). Bu hüküm ile yukarıda ifade edilen ve 31/12/2022 tarihine kadar ertelenen vergilerin ve içme ve kullanma suları için alınacak ücretlerdeki indirimle alakalı hükümlerin kırsal mahalleler ve kırsal alanlar için artık uygulanmadığı görülmektedir.

Ayrıca, orman köyü, kasabası veya beldesiyken mahalleye dönüşen yerlere mevzuat ile (5393 sayılı Belediye Kanunu'nun 12. maddesinin 7. fikrası ile 6831 sayılı Orman Kanunu'nun ek 17. maddesi hükümleri) tanınan hak, sorumluluk ve imtiyazların, bu maddedeki muafiyet ve indirimler ile çakışması durumunda bu madde (7254 sayılı Kanun Mad. 10) hükümleri uygulanacaktır.Ayrıca, diğer hak, sorumluluk ve imtiyazların korunmasına devam edilmektedir.

Bu yasa teklifinin yanı sıra yine Ekim ayında AK PARTİ, "Yerel Yönetimler Yasa Taslağı"nı nihayete erdirmiştir. Taslak içerisinde "hayatı kolaylaştıracak çok fazla konu olduğunu" vurgulayan AK PARTİ Yerel Yönetimlerden Sorumlu Genel Başkan Yardımıısı Mehmet Özhaseki, kırsal alanlara ilişkin şu ifadeleri kullanmıştır (AA, 2020):

"30 büyükşehirde köyleri kaldırdık, mahalle dedik buralara. Kırsal yerlerde 10 dönüm tarlasının içerisinde bir evi olan vatandaş oraya bir oda yapacağı zaman öyle bir prosedürden geçiyor ki perişan oluyor. Biz taslağımızda, 'Vatandaşı perişan etmeye gerek yok, bunu kolaylaştıralım. Bir taslak proje alsın, ilgili belediyeye müracaat etsin. Oradaki belediye izin verince devam etsin. Vatandaşı yormayalım. Uzun masraflar ettirmeyelim. Köylü 15 bin liraya bir oda yapacak, 10 bin lira masraf ettirmeyelim.' diyoruz. Su bedelleriyle ilgili bazı sıkıntılar oluyor. Bazen köy statüsü içinde kalıp da istisnalardan istifade eden sanayi tesisleri ve alışveriş merkezleri oluyor. Ne yapacağı, vergi muafiyeti mi getirelim alı̧̧veriş merkezlerine? Bunun için yeni bir kavram geliştirmek lazım. Onun da belediye meclislerinde kararlaştırılması lazım: 'Kırsal alan' kavramı"

Kırsal mahalleler ve kırsal alanlara ilişkin kanun teklifi ve taslağının dışında, 18 Ekim 2020 tarihinde TBMM'ye 2021 yılı Merkezi Yönetim Bütçe Kanun Teklifi sunulmuştur. T.C. Cumhurbaşkanlığı Strateji ve Bütçe Başkanlığı’nın web sayfasında belirtilen bütçe kanun teklifi özetinde yerel yönetimlerle ve tarımsal üretimle ilgili önemli bütçe artışları öngörülmüştür.

Yerel yönetimlere aktarılan kaynak, 114 milyar TL seviyesine ulaşmıştır. Özellikle yukarıda bahsi geçen KÖYDES projesi kapsamında 1,6 milyar TL, belediyelerin su ve kanalizasyon altyapılarını güçlendirmek için oluşturulan SUKAP (Su Kanalizasyon Altyapı Projesi) projesi kapsamında 897 milyon TL bütçeden ayrılmıştır.

Yeni bütçe kanun teklifinde dikkati çeken bir diğer nokta ise tarımda sulama ve içme suyu yatırımları için aktarılan kaynağın iki kattan fazla artmasıdır. Tarıma ayrılan kaynakta 2020 yılı bütçesine göre 9 milyar TL bir artış olmuştur. Bu sayede önümüzdeki yıl bütçesine tarıma aktarılacak pay 42,4 milyar TL olarak öngörülmüştür.

Bu kapsamda, tarımsal destek programları için 22 milyar TL, tarım sektörü yatırımları için 12,1 milyar TL, tarımsal kredi sübvansiyonu, müdahale alımları, tarımsal KİT'lerin finansmanı ve ihracat destekleri için 8,3 milyar TL kaynak 
ayrılmıştır. Bütçe kanun teklifinin genel gerekçesinin içinden tarıma yönelik aktarılan payların gerekçesi; “tarımda üretim ve verimlilik artışını; yeni nesil girişimciler, teknolojiler, girdi bazlı destekleme ve sözleşmeli tarımla sağlamak” şeklindedir.

\section{SONUÇ}

Yeni büyükşehir modelinde kırsal mahalle olarak nitelendirilen, 6360 sayılı Kanun’un yürürlüğe girmesinden önce ise köy ve belde tüzel kişilikleri içerisinde kendi kararlarını kendileri alabilen yerel yönetim birimlerine artık hizmetlerin belediyeler eliyle sunulacak olması avantaj ve dezavantajları beraberinde getirmiştir. Yeni büyükşehir modeli, kırsal mahallelere; hizmetlerin daha kaliteli sunulması, özellikle temel altyapı, içme ve kullanma suyu sağlama, kanalizasyon, tarımsal arazi kullanım planları yapma gibi temel hizmetlerin daha büyük ölçekteki güçlü birimler eliyle yapılması gibi avantajlar sağlamaktadır. Bunun gibi avantajlara rağmen; kırsal mahallelerde yaşayanlara getirilen mali yük, eskiden köylere ait çayır, mera gibi alanların belediyelerin tasarrufunda olmasının tarım ve hayvancılık faaliyetlerini olumsuz yönde etkilemesi, kırsalda temsil ve siyasal katılım kanallarının daraltılması, belediyelerin tarımsal faaliyetlerle ilgili alt yapısının olmaması gibi dezavantajlar da ilgili yazında eleştiri konusu olmaktadır.

Kırsal mahalleler konusunun literatürde geniş bir yer tutması, kırdan kente göç olgusunun getireceği kentsel sorunların artışı gibi konuların yoğun bir biçimde tartışılması bu mahallelere yönelik yapılan düzenlemeleri daha da önemli hale getirmektedir. Bu çalışma, kırsal mahallelerin önemi ile bu mahallelere yönelik güncel gelişmeler ve yasal düzenlemeleri konu edinmiştir.

Kantar Davran ve Tok'a (2018:2142) göre; “İnsanların fiziki ve insani gereksinimlerini karşılamaya yetecek mal ve hizmetleri alamama olarak tanımlanabilen 'yoksulluk' ile bunlara erişememe olarak tanımlanabilen 'yoksunluk', kırsal alanda yaşayanları daha fazla etkilemektedir”. Kırsal mahallelerde yaşayan halk hem yoksullukla hem de yeterli ve kaliteli sağlık, eğitim, kültürel, bayındırlık hizmetleri ve benzeri hizmetlerden yoksunlukla mücadele etmektedir. Yeni büyükşehir modeli ile kırsal alanların kentsel alanlar şeklinde konumlandırılması ile belediye hizmetlerinin kırsal mahallelere götürülmesi, bir bakıma hizmetlerin bir kısmı açısından yoksunlukları telafi edebilecek ise de yoksullukları ortadan kaldıracak düzenlemelerin daha gerekli olduğu söylenebilir. Bu nedenle kırsal mahallelerin yoksulluk ve yoksunluklarının giderilmesi devletin yürüteceği politikalara ve kırsal mahalle vatandaşına sağlayacağ 1 yeterli mali destek ve kamu hizmetlerine bağlıdır.

Büyükşehirlerde kırsal ve kentsel mahalle ayrımının yapılması en başta adalet duygusu ile alakalıdır. Temel kentsel hizmetlere ulaşabilen kentsel mahalle vatandaşının ödeyeceği vergi ile yoksunluk ve yoksullukla mücadele eden, tarım ve hayvancılıkla geçinen kırsal mahalle vatandaşının ödeyeceği verginin eşit olmaması gereklidir. Bu nedenle hem kırsal mahallede yaşayanların kentlere göç etmesini önlemek, hem de tarımsal üretimin sürekliliğini sağlamak açısından yasal düzenlemelere ihtiyaç bulunmaktadır.

Bu konudaki son gelişmeler çalışmada belirtilmiştir. Bunlardan en önemlisi 16 Ekim 2020 tarihli 7254 sayılı Kamu Mali Yönetimi ve Kontrol Kanunu ile Bazı Kanunlarda Değişiklik Yapılması Hakkında Kanun ile yapılan düzenlemelerdir. $\mathrm{Bu}$ düzenleme ile büyükşsehir belediyesi sınırlarında olan ancak kırsal özellikleri ile kentlerden ayrılan, kent merkezine uzak, sosyolojik açıdan köy özellikleri gösteren, tarım ve hayvancılığa dayalı bir ekonomisi olan mahalleler, bağlı oldukları belediye meclislerinin kararı ve teklifi üzerine büyükşehir belediye meclisinin kararı ile kırsal mahalle olarak kabul edilerek mali avantajlar kazanmaktadır. Bu düzenlemeye paralel olarak AK PARTI'nin hazırladığı "Yerel Yönetimler Yasa Taslağı" hakkındaki açıklamalarda da köylünün mali anlamda mağdur edilmeyeceği açıkça dile getirilmiştir. Bu gelişmelerin yanı sıra bütçe kanun teklifi ile tarımsal projelere yönelik yapılan bütçe artışları da dikkate değer görünmektedir. Ancak bütün bu olumlu düzenlemelere rağmen kırsalda yaşayan halk, gün geçtikçe kentlere doğru göç etmektedir. Bu, yerelden ziyade başlı başına ulusal bir sorundur. Bu kapsamda yapılan düzenlemeler geçici olarak bir rahatlama sağlasa da sorunun uzun vadede çözümü için yeterli görülmemektedir. Maddi imkanlar ve avantajların yanı sıra bu sorunun çözümü için ulusal düzeyde sürdürülebilir politikaların üretilmesi gereklidir. 


\section{Etik Standart ile Uyumluluk}

Çıkar Çatışması: Yazarlar herhangi bir çıkar çatışmasının olmadığını beyan eder.

Etik Kurul İzni: Bu çalışma için etik kurul iznine gerek yoktur.

Finansal Destek: Yok.

Teşekkür: Yok.

\section{KAYNAKÇA:}

5216 Sayılı Büyükşehir Belediye Kanunu. Resmî Gazete, 25531, 23.07.2004.

6360 Sayılı On Dört İlde Büyükşehir Belediyesi ve Yirmi Yedi İlçe Kurulması ile Bazı Kanun ve Kanun Hükmünde Kararnamelerde Değişiklik Yapılmasına Dair Kanun. Resmî Gazete, 28489, 12.11.2012.

7254 Sayılı Kamu Malî Yönetimi ve Kontrol Kanunu ile Bazı Kanunlarda Değişiklik Yapılması Hakkında Kanun. Resmî Gazete, 31276 (Mükerrer), 16.10.2020.

Ayyıldız, M., Çiçek, A., Ayyıldız, B. (2016). 6360 Sayılı Büyükşehir Yasasının Kırsal Kesime Olası Etkileri. Nevşehir Bilim ve Teknoloji Dergisi TARGiD Özel Sayı. 280-285.

ÇŞB. Çevre $\quad$ ve Şehircilik $\quad$ Bakanlığı $\quad$ (2010). https://webdosya.csb.gov.tr/db/kentges/editordosya/kentges_tr.pdf adresinden alındı.

Özçağlar, A. (1996). Türkiye'nin İdari Coğrafyası Bakımından Köy, Bucak, İlçe, İl ve Belde Kavramları Üzerine Düşünceler. Ankara Üniversitesi Dil ve Tarih-Coğrafya Fakültesi Coğrafya Araştırmaları Dergisi (12), 7-24.

Özçağlar, A. (2005). Türkiye'de Mülki İdare Bölümlerinin İdari Coğrafya Analizi. Coğrafi Bilimler Dergisi, 3(1), 1 25.

AA. Anadolu Ajans1. (2020, Ekim 03). Anadolu Ajans1. https://www.aa.com.tr/tr/politika/ak-partinin-yerelyonetimler-yasa-taslagi-hazir/1601405 adresinden alındı

Dik, E. (2014). 6360 sayılı Kanun Bağlamında Köylerin Mahalleye Çevrilmesi Sorunu. Mülkiye Dergisi, 38(1), 75 102.

E-içişleri. (2020). İçişleri Bakanlığı Mülki İdare Birimleri. https://www.eicisleri.gov.tr/Anasayfa/MulkiIdariBolumleri.aspx adresinden alındı

Ekinci, E. (2020a). Hizmet Sunumundan Hukukilik Boyutuna: 6360 Sayılı Kanun'a Yönelik Akademik Eleştiriler. Türkiye Siyaset Bilimi Dergisi, 3(1), 89-115.

Ekinci, E. (2020b). 6360 Sayılı Kanun'un Temsil ve Hizmet Kalitesi Yönünden Kapatılan Belde Belediyelerine Etkisi ve Vatandaşın Algısı: Hatay İli Örneği. Kırıkkale Üniversitesi Sosyal Bilimler Enstitüsü Yayınlanmış Doktora Tezi.

Ekinci, E. (2020c). Yeni Büyükşehir Modelinde Temsil, Katılım ve Hizmet Kalitesi. Ankara: Gazi Kitabevi.

Erkan, R. (2010). Kentleşme ve Sosyal Değişme. Ankara: Bilimadamı Yayınları 3. Baskı.

Eryılmaz, B. (2017). Kamu Yönetimi. Kocaeli: Umuttepe Yayınları.

Gözler, K. (2018). Mahalli İdareler Hukuku. Bursa: Ekin Yayınevi.

Gözler, K. (2013). 6360 Sayılı Kanun Hakkında Eleştiriler: Yirmi Dokuz İlde İl Özel İdareleri ve Köylerin Kaldırılması ve İlçe Belediyelerinin Büyükşehir İlçe Belediyesi Hâline Dönüştürülmesi Anayasamıza Uygun mudur?. Legal Hukuk Dergisi, 11(122), 37-82.

Hazar, D. (2017). Kır-Kent Çeperinde Ekolojik Yaklaşım. Şehir\&Toplum Dergisi (7), 135-142.

Ünal, A. (2016). Kırsal ve Kentsel Alan Tartışmasında Belediyeler. İller ve Belediyeler Dergisi (821-822), 50-54. 
Kantar Davran, M., Tok, N. (2018). Kırsal Kesimde Yoksulluk Algısı ve Yaşam Memnuniyeti. International Journal of Social Humanities Sciences Research (JSHSR). 5(25). 2140-2152.

Kartal, N., \& Demirhan, Y. (2015). Yerel Hizmetlerin Kırsal Alanlara Götürülmesi ve Kent Belediyeciliğinden Alan Belediyeciliğine Geçiş: Bir Model Önerisi. Dicle Üniversitesi Sosyal Bilimler Enstitüsü Dergisi, 7(13), $384-402$.

KB. Kalkınma Bakanlığı (2014). Bölgesel Gelişme Ulusal Stratejisi. https://sbb.gov.tr/wpcontent/uploads/2018/11/2014-2023_B\%c3\%b6lgesel_Geli\%c5\%9fme_Ulusal_Stratejisi.pdf adresinden alınd1.

Mert, M. (2014, Mart 3). Büyükşehir (Bütünşehir) Yasasının Tarıma ve Kırsala Etkileri. Pusula Gazetesi: http://www.pusulagazetesi.net/kose-yazilari/buyuksehir_butunsehir_yasasinin_tarima_ve_kirsala_etkileri-2039.html adresinden 15.10.2020 tarihinde alınd.

TBMM. (2013). TBMM Komisyon Raporu (435 Sira Sayılı, 24. Dönem 3. Yasama Y1l1). https://www.tbmm.gov.tr/develop/owa/sirasayi_gd.sorgu_yonlendirme?donem_kodu=24\&Sirasayi_no=435\&Baslangi c_Tarihi $=\&$ Bitis_Tarihi $=\&$ sorgu_kelime $=$ adresinden alınd1.

TheWorldBank. (2020). The Wolrd Bank Data https://databank.worldbank.org/reports.aspx?source=2\&series=SP.URB.TOTL.IN.ZS\&country= adresinden 10.10.2020 tarihinde alınd1.

Ulusoy, A., \& Vural, T. (2001). Kentleşmenin Sosyo Ekonomik Etkileri. Belediye Dergisihttp://kadirgurbetci.com.tr/yonetim/dosya/e8fd2e0154hnk.pdf adresinden 20.04.2020 tarihinde alınd1., 7(12), 8-14.

Yılmaz, C. (2019). Türkiye Kırsal Yerleşme Coğrafyası Literatürü. Türkiye Araştırmaları Literatür Dergisi, 17(34), 519-560.

Yılmaz, M. (2016). Türkiye'de Kırsal Nüfusun Gelişimi (1927-2012). Türkiye Belediyeler Bilrliği İller ve Belediyeler Dergisi (821-822), 46-49.

Yaslıkaya, R. (2014). 6360 Sayılı Yasanın Uygulanmasında Yaşanan Sorunlar: Mersin Büyükşehir Belediyesi Örneği. Uluslararası Türk Dünyası Yerel Yönetimler Sempozyumu. Gazi Magusa/Kıbrıs. 